\title{
Constructing patriotism: How Canada's History Hall has evolved over 50 years
}

\author{
Cynthia Wallace-Casey* - University of Ottawa, Canada
}

\begin{abstract}
In this article, I illustrate how the national narrative in Canada's Museum of History has evolved over 50 years. Located in the national capital of Ottawa, the new Canada's History Hall presents a concise overview of a nation, stretching from time immemorial to the present. It was opened on 1 July 2017 as a signature exhibition in celebration of Canada's sesquicentennial. It also represents a fourth manifestation of a national museum narrative for Canada. From humble beginnings in 1967 (when Canada celebrated its centennial), the narrative has changed substantially in response to national policies and societal values. Adopting a critical discourse analysis methodology, and drawing from archival evidence, I analyse how this national narrative has evolved. Canada's History Hall presents Canadian students with a concise national template for remembering Canada's past. Over the past 50 years, this narrative has changed, as curators have employed artefacts and museum environments to construct patriotic pride in their nation. Until 2017, this narrative was blatantly exclusionary of Indigenous voices. More recently, the Truth and Reconciliation Commission of Canada has called for reconciliation in education, including public forums for education. The Canadian Museum of History has responded to this call by weaving Indigenous voices into the national narrative of the new Canadian History Hall. In so doing, I argue, the museum has successfully entwined patriotism with reconciliation against past wrongs.
\end{abstract}

Keywords: museums; national narratives; patriotism; Indigenous history; Canada; Canadian Museum of History; Truth and Reconciliation Commission of Canada

\section{Introduction}

The New Canadian History Hall that opened in Ottawa's Canadian Museum of History on 1 July 2017 is not really all that new. It actually represents an evolution in history halls that can be traced back to 1967, when Canada celebrated its centennial as a nation. In this article, I illustrate how the national narrative in Canada's Museum of History has evolved over 50 years. I also analyse how the experiences of Indigenous peoples have (or have not) been included within these national narratives. With each manifestation of Canadian history, Canada's national museum has constructed a 'big idea' about what it means to be Canadian. Each of these manifestations represents a concise national template for student learning about Canada's past.

\section{Planning for Canada's centennial year, 1967}

The concept of a national exhibition, representing Canada in its entirety, was first initiated in 1959, when the then Prime Minister, John G. Diefenbaker, announced the start of planning for Canada's centennial year of 1967. Two years later, parliament 
passed the National Centennial Act (later to be amended and renamed in 1963 as the Centennial of Confederation Act), establishing an administrative framework for federal involvement in centennial celebrations. What followed would be the establishment of a Centennial Commission, with a broad mandate to promote interest in the centennial, and to plan programmes and projects related to the centennial's historical significance.

As part of this planning initiative, Canada's national museum, which was then known as the Victoria Memorial Museum, was transferred from the jurisdiction of the Department of Northern Affairs and Natural Resources, to the Department of the Secretary of State. This marked a significant change in leadership, since the secretary of state was responsible for a much broader (interdepartmental) mandate of ceremonial and state duties - including citizenship. Plans were subsequently established for assembling historical collections to celebrate the first 100 years of Canadian Confederation, and cabinet instructed the Human History Branch of the museum to begin collecting historical objects for display in a new museum building that would be opened in 1967.

By the end of March 1964, the National Museum of Canada consisted of two branches: the Natural History Branch, and the Human History Branch. Within the Human History Branch, there were sections responsible for archaeology (including physical anthropology), ethnology, war and aviation. A Canadian History Section, although already mandated, was yet to be organized; it was nevertheless reported that plans were already well under way for a 'Canadian Historical Museum', to be housed separately from the other branches and sections of the national museum. The intent was to establish a permanent exhibition, depicting Canada's human past from 28,000 $B C$ to $A D$ 1967, and adding to the already existing array of exhibitions that focused on Canada's ethnology, archaeology and folklore (Thorpe, c.1980). This concept was described in the museum's Annual Report of 1964 as follows:

This new museum will deal with Canadian History in the broadest sense. Starting with a review of Man's place in Nature, it will trace the entry and spread of aboriginal people into North America from Asia, and the development of their cultures as revealed by archaeological and ethnological evidence. The section dealing with European man in Canada will follow the routes of the early explorers, fur traders, and missionaries. It will represent not only the great events that shaped the development of this country, but will also show the way of life of Canadians from the first settlers, to the generation before the present. Pioneer arts, crafts, and industries will have a prominent place, so will also the counsel of social history for illustration of Canadian participation in several armed conflicts, including extensive subsections illustrating the armaments of the two world wars.

Exhibits illustrating the way of life of Canada's Eskimos and Indians are now being built in the National Museum. The historical collections of the Public Archives other than documents and the Department of Agriculture are in process of being turned over to the National museum for incorporation in the Historical Museum. Large collections of furniture, utensils, tools, vehicles, textiles, clothing, and craft products are being assembled, from which can be prepared exhibits showing household interiors, craft shops, business establishments, and professional offices as they might have been in Canada of the 17th, 18th and 19th centuries. Series of objects will show the development of agriculture, of woodworking, of lighting and heating, 
and of many specialized crafts. Special facilities will be provided to permit demonstration of the actual crafts and arts of the past. Here in the Canadian Historical Museum will be seen the march of events in the past, and the manner in which our ancestors met the challenge of a new land, and expanded their economy and industry. (Secretary of State, 1964: 21)

In response to the Canadian cabinet's call to action, historians were appointed whose primary role was to develop an artefact collection representing Canada as a nation. Leadership came from the museum's first History Division Director, Frederick J. Thorpe, as well as a new Museum Director, Richard Glover, both of whom were hired in 1964. These two individuals, along with four other historians who were on staff by 1967, became key to framing what artefacts the museum would acquire, and what stories the museum would tell about Canada's past.

With the arrival of Richard Glover as museum director, however, plans for a new history museum were quickly postponed, with the intent of adopting a new plan that would combine both human and natural history into a single building (Secretary of State, 1965: 18). Later, as centennial year drew closer, plans for a new building fell through completely, as government priorities shifted towards construction of a national arts centre, as well as the construction of a national archives building. The official centennial project for the Human History Branch of Canada's National Museum would become nothing more than a humble series of exhibits, presented on the mezzanine level of the museum, documenting Canada's entry into Confederation. This became Canada's first History Hall (see Figure 1).

\section{7: Canada's first History Hall}

Confederation 1867 was a modest exhibition - covering 'several thousand' square feet (Secretary of State, 1968: 35) - that commemorated 'events leading up to and including the Act of Confederation' (ibid.: 30). The exhibition included period rooms, material culture and information on the social, economic and political history of the period:

On the mezzanine three rooms of furniture of the confederation period were set up and showcases displayed artifacts relating to personal trinkets of the period. In the rotunda artifacts were on display relating to the agriculture, fishing and industry of confederation times, along with an exhibit of Fathers of Confederation belongings - Sir John A. MacDonald's desk, chairs and an epergne [a table] belonging to Sir George-Étienne Cartier and four statuettes of MacDonald, Cartier, Tupper and Langevin. (ibid.)

By today's standards, the choice to focus specifically on four (out of a total of 36) 'Fathers of Confederation', namely Sir John A. MacDonald (Canada's first Prime Minister, who was a representative for Upper Canada - now known as Ontario), Sir George-Étienne Cartier (a representative for Lower Canada - now known as Quebec), Sir Charles Tupper (a representative for Nova Scotia) and Sir Hector-Louis Langevin (a representative for Lower Canada), seems extremely exclusionary. In hindsight as well, the choice of commemorating Sir Hector-Louis Langevin is particularly inappropriate, since Langevin has since been identified as a prominent 'architect' (along with Sir John A. MacDonald) in establishing Residential Schools for Indigenous peoples in Canada (see Hayday, 2017). 


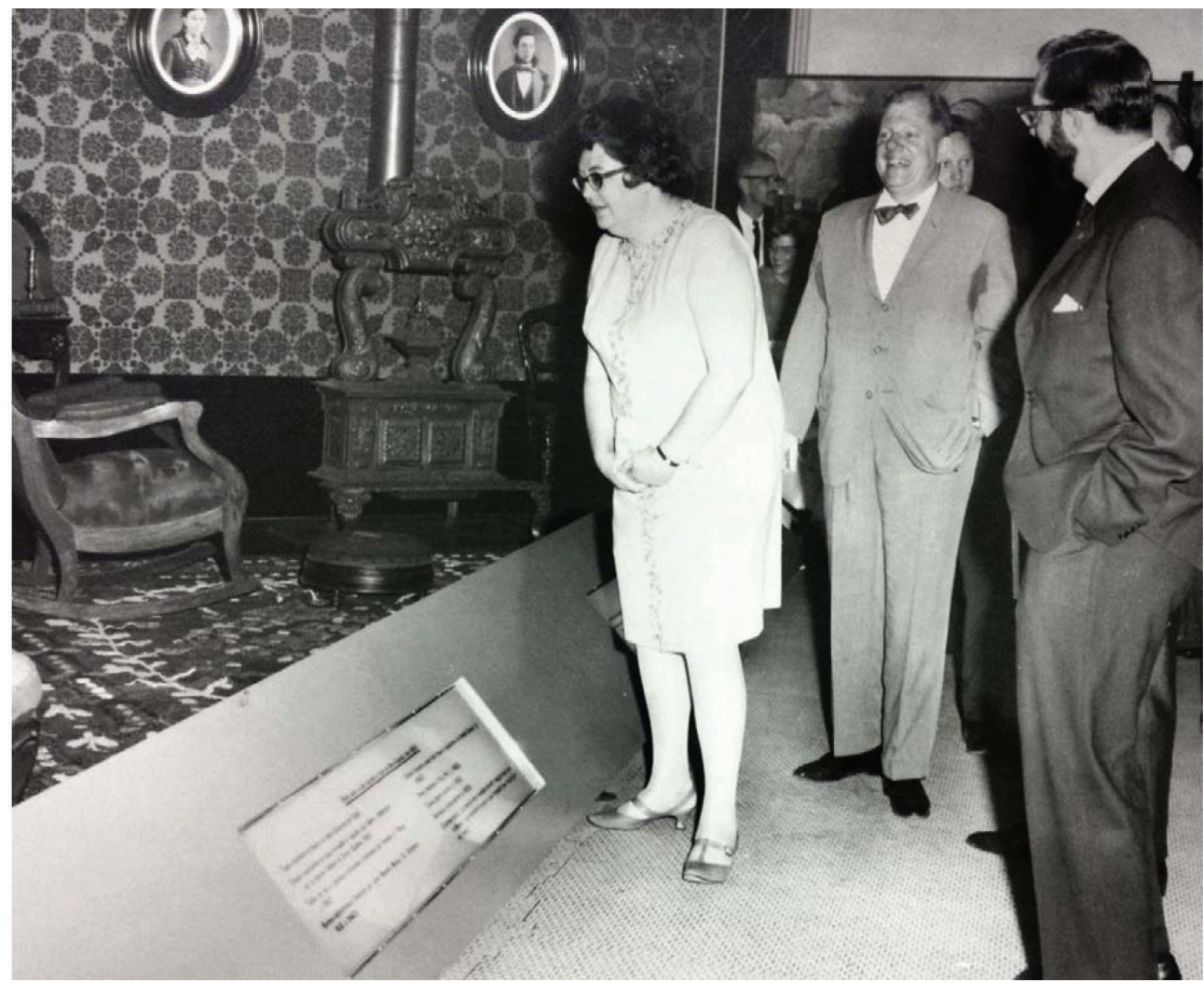

Credit: Canadian Museum of History

Figure 1: Confederation 1867 - Secretary of State Judy LaMarsh (left) opened the museum's first History Hall on 26 June 1967, along with History Division Director Frederick Thorpe (centre) and Museum Director William Taylor (right)

This was Canada's first History Hall and, by all accounts, no Indigenous history was included in the interpretative storyline. Instead, Indigenous history was presented separately in other parts of the museum building. This exclusionary practice followed divisionary lines within the museum that perpetuated what former History Division Director Frederick J. Thorpe has described as a Darwinian approach to the past. In this sense, museum spaces were divided according to an evolutionary progression, stretching 'from earth sciences [natural history] by way of paleontology to life sciences, and from life sciences [human history] in general to aboriginal man and from aboriginal man to so-called civilized man' (Thorpe, c.1980: 3). Earth sciences occupied the east side of the building, while life sciences occupied the west side. Correspondingly, within the Human History Branch of the museum, the history of 'aboriginal man' fell under the curatorial interests of the archaeology and ethnology divisions, while the history of 'civilized man' fell under the curatorial interests of the History Division (Secretary of State, 1968: 31-6; see also Thorpe, c.1980: 20-1). Other exclusionary practices included the renaming of the National Museum of Canada as the National Museum of Man, an action that was brought about largely by the popularity of Expo 67 in Montreal, which was called Man and His World (Vodden and Dyck, 2006: 62).

For students visiting the National Museum of History during centennial year, Indigenous voices were blatantly absent from the narrative about Canada's past. Instead, Indigenous peoples' history was presented elsewhere in the building (outside the national narrative). In addition, one of the highlights of their summer learning experience would have been 'Indian days', in which children aged 10 to 12 participated in a week-long summer camp (Secretary of State, 1968: 26), which involved lectures, crafts and games: 
The daily program lasted from 9:30 a.m. to 4:00 p.m., starting in the morning with an illustrated lecture. In the afternoon, games were played, sometimes authentic Indian dances, and crafts such as modelling in plasticine, making and painting of drums, and artwork were enjoyed. The painting of authentic Plains Indian designs on a full-sized tipi was the focal point of the program. These tipis looked very attractive when finished and set up on the grounds of the Museum and were a source of pride to the boys and girls. An air of authenticity was added by choosing 'chiefs' for each 'tribe', and praises were given to those children who had done the best craft work. (ibid.: 25)

In the age of the 'Sixties Scoop' (the practice, during the 1960s, of taking - 'scooping up' - children of Aboriginal peoples in Canada from their families for placing in foster homes or adoption, with each region having its specific adoption or fostering programme and policy), eugenics and Residential Schools, such activities did little to enlighten students on Indigenous experiences in Canada. Instead, the museum's education practices served only to encourage cultural appropriation of traditions that were quickly disappearing or were already extinct.

So, while the vision of establishing a Canadian Museum of History was not realized in time for Canada's centennial celebrations, there did begin to evolve a concept of a Canadian History Hall. This notion, however, was extremely exclusionary, and followed Darwinian lines of interpretation. Indigenous voices were clearly absent from any notion of a national narrative, and students' only exposure to Indigenous history was through methods of cultural appropriation. Nevertheless, on the day in 1967 when Secretary of State Judy LaMarsh cut the ribbon to open the first Canadian History Hall, plans were already well under way for renovations that would eventually make way for a much more significant exhibition that would open 10 years later, in 1977 (Thorpe, 1978: 66).

\section{7 - A Few Acres of Snow - Quelques arpents de neige}

A Few Acres of Snow - Quelques arpents de neige (see Figure 2) drew its title from a popular quote by French writer Voltaire (1759: 33), who wrote: 'those two nations [England and France] are fighting a war over a few acres of snow in Canada and they're spending more on that glorious war than the whole of Canada is worth'. It was this citation that set the stage for a colonial perspective on Canada's past that drew upon the environment as a unifying factor for a nation. The intent of this national narrative was to present the 'history and heritage of the everyday Canadian' - by drawing Canadians together through shared objects, shared environments and shared experiences (National Museum of Man, 1977: 1).

The common narrative thread for this greatly enlarged version of the Canadian History Hall (covering 8,000 square feet of exhibit space) was Canada's environment. The 'big idea' was that Canada's northern climate has made us who we are as Canadians, that national identity flows out of the exploitation of natural resources - fish, fur, timber and coal - as well as technology developed to aid in this exploitation, and that such acts of exploitation have had human as well as environmental consequences (Ruddel, 1983; see also Friesen, 1978). This storyline was achieved through a combination of didactic and dioramic learning environments. Thematic choices were largely driven by the research interests of curatorial staff, along with the artefact collection and current trends in social history (Gallacher, 2009: 27-9). 


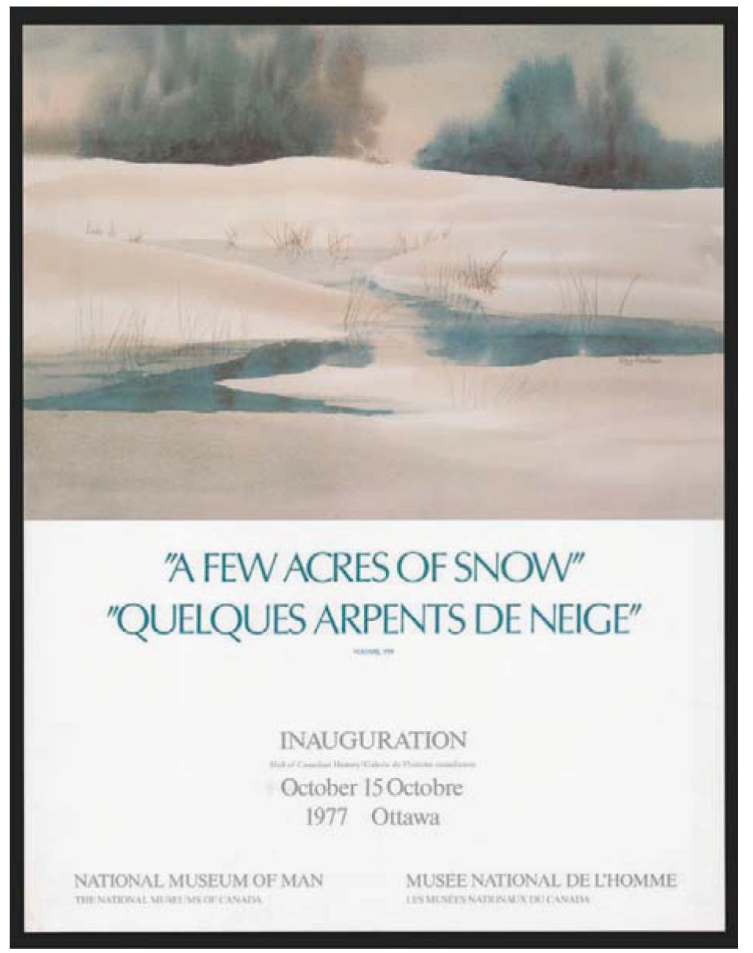

Credit: Library and Archives Canada

Figure 2: A Few Acres of Snow - Quelques arpents de neige, opened on 15 October 1977

As the museum's official press release explained, this national storyline commenced with a brief reference to 'Early Man's' interaction with the environment, and quickly moved on to the arrival of Europeans. Then followed thematic units that explored Europeans against the wilderness, the environment and [European] man, nineteenthand twentieth-century rural life, urban development, and eighteenth- to twentiethcentury Canadian society. Some of the features within these units included dioramas of the interior of an immigrant ship crossing the Atlantic; a Depression-period kitchen from Saskatchewan; a coal mine from Glace Bay, Nova Scotia; and a wealthy lateVictorian parlour. This History Hall ended with a section on Canadian identities, where visitors were reminded that 'we' were all immigrants at some point in time, and that 'all Canadians, past and present, have had much more in common than they believe possible' (National Museum of Man, 1977: 7).

Clearly, the 1977 version of Canada's History Hall was firmly rooted in settler colonialism. Within this national narrative, Indigenous history was largely excluded after the initial introductory unit, where Indigenous people were presented as redskinned and naked. The only other fleeting reference could be found relating to the fur trade in New France, where Indigenous peoples were credited as 'essential to the growth of this industry' by providing 'the French with fur pelts and practical modes of travel-snowshoes, toboggans, and canoes' (ibid.: 8); then, at the very end of the Hall, it was recognized that 'Canada's native peoples seek a strong voice in deciding their own future, for their past, since contact with Europeans, has been largely controlled for them' (ibid.: 51).

The reasoning behind such a brief acknowledgement of an Indigenous presence within the History Hall was that Indigenous peoples were interpreted separately within the museum - as ethnology, rather than history. As visitors made their way through the 
National Museum building, they travelled through four million years of time, beginning with The Immense Journey Hall on the first floor, where they encountered dioramic domes, and progressed through societal themes. Visitors then explored the Canada Before Cartier Hall, where they learned the 'pre-history' of Canada (Thorpe, c.1980: 21). Canada's History Hall occupied the fourth (and final) floor of the museum. In this sense, the colonial experience was clearly separated from Indigenous experiences, and visitors progressed upwards through the building, towards modern 'civilized' society. Here, Canadian identity was presented as the product of 'shared historical experiences' that were 'unique to this country and to the non-Indigenous peoples who settled it' (National Museum of Man, 1977: 1). In this context, the message was loud and clear: 'Canada' began with the arrival of French explorer Jacques Cartier in 1534, and Canadian identity is the product of non-Indigenous peoples.

Within the broader perspective of Canadian society, a settler colonial past did not seem at all problematic at the time. Canada, it seemed, was experiencing an identity crisis, and A Few Acres of Snow provided a welcome message of unity. It was a sign of the times, since by 1977 many Canadians were concerned about the future of Confederation, as Separatist forces were gaining ever greater momentum in Quebec under the leadership of Provincial Premier René Lévesque. Combined with this crisis was the emergence of federal policies aimed at supporting 'multiculturalism within a bilingual framework' (Haque, 2012), as well as strengthening cultural industries against competition from the United States. As Mackey (1999: 50) has pointed out: 'Multiculturalism was developed as a mode of managing internal differences within the nation and, at the same time, created a form through which the nation could be imagined as distinct and differentiated from external others such as the United States.'

The problem, however, was that Indigenous peoples were not included in this imaged nation. So, while exhibition reviewer Jean Friesen (1978: 65) observed that $A$ Few Acres of Snow offered 'a story in which most Canadians can find their relevant place', and while Museum Director William Taylor emphasized how the narrative illustrated 'the commonalty of our historical experience' (National Museum of Man, 1977: 1), Indigenous Canadians were markedly absent from this collective identity. For students visiting Canada's History Hall in 1977, Indigenous Canadians were the culturally primitive other, exhibited elsewhere in the building.

\section{9 - Canada's History Hall: New Beginnings}

When A Few Acres of Snow was unveiled in 1977, plans were already well under way to establish a new museum facility that could better serve the curatorial, administrative and public programming needs of a national museum (MacDonald and Alsford, 1989: 7-8). This new facility opened in 1989, along with a new name, the Canadian Museum of Civilization. Within this impressive piece of architecture stood a new (and substantially larger) Canada History Hall that covered 43,558 square feet of exhibit space.

New Beginnings was the working title for this state-of-the-art streetscape-style exhibition, which portrayed Canada's human experience through a continuous storyline that spanned a thousand years of history (see Figure 3). The intent of this much larger national narrative was to present the 'story of how generations of Canadians have faced new and challenging situations as they moved from one frontier to another' (ibid.: 97-8). This was a very ambitious undertaking. As the museum's Director of History, Dan Gallacher (2009: 4) later recalled, New Beginnings presented Canada's history on an epic scale. 


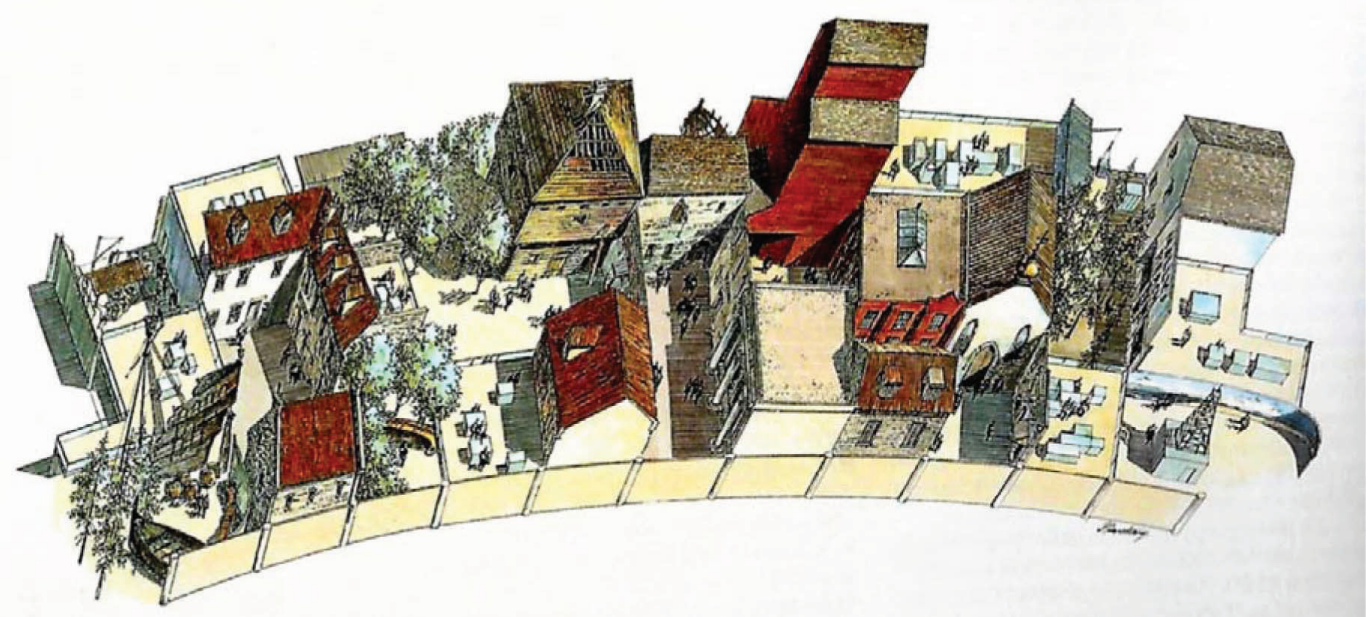

Credit: Canadian Museum of History

Figure 3: New Beginnings, the working title for a state-of-the-art streetscape-style Canadian History Hall that opened in the Canadian Museum of Civilization in 1989

What set this History Hall distinctly apart from previous versions was that the curatorial design process was largely market-driven; so, while well researched in impressive detail, history played a secondary role in the exhibition design process (Gallacher, 2009: 34; see also Rider, 1994). Each streetscape unit was intended to serve as a museum 'table of contents' for national historic sites located across Canada (MacDonald and Alsford, 1989: 99), commencing with the arrival of Vikings at L'Anse aux Meadows in Newfoundland in c.1000, and stretching into the present, with the Wildcat Café at Yellowknife in the Northwest Territories. The common narrative thread for this interpretation of Canada's past was a unifying spirit of exploration and adventure:

It is the story of how generations of Canadians, both new and old, faced new and challenging situations. And it is the story of the dreams and spirit of adventure that moved Canadians from one frontier to another. The waves of immigration, the movement of people of many different backgrounds across a wilderness country, the growth of cities, the challenge of the environment, and the far-reaching changes in technology and social development are all part of this history. All had a profound impact on the daily lives of Canadians. (Champoux-Ares, 1986: 26)

This storyline was to be achieved through experiential (rather than didactic) learning, about how ordinary citizens lived much of their ordinary lives. As a result, learning environments were constructed (by order of priority) to be: (1) evocative of adventure and discovery; (2) entertaining; (3) emotionally stimulating; and (4) participatory (ibid.: 16). In this context, entertainment took precedence over information, and actual museum artefacts were not necessary. Artefacts, it was reasoned, could be exhibited elsewhere in the museum (ibid.: 17).

Once again, Canada's History Hall presented a story of settler colonialism. The 'big idea' was that Canada constitutes a cultural mosaic of people from many different backgrounds, and that 'the interaction of these cultures has both changed individual cultures and produced a meeting point' (MacDonald and Alsford, 1989: 99) for a national identity that is uniquely Canadian. One of the most evident problems with this national narrative, however, was that Indigenous peoples were (yet again) 
virtually excluded. According to this storyline, 'Canada' began with the arrival of Vikings in c.1000. Progress in the 'New World' was then followed by a 'Taking Root' of New France, and 'Expanding Frontiers' in British North America - where 'Towns and Trade' grew, along with the expansion of the 'Western Interior' after Confederation. This story of Canada's past ended with a celebration of the hinterlands within the 'Far Horizons' of British Columbia, the Yukon and Northwest Territories (see Canadian Museum of History, n.d.(a)). Throughout Canada's History Hall, the experience of Indigenous peoples was rarely evident. This national narrative was purely a story of colonization through a western and northern movement of expansion. Indigenous voices were hauntingly absent.

The problem was that although Indigenous voices were well represented on the main floor of the museum, within space that featured the breathtakingly elaborate Grand Hall (a signature space in the museum to this day), Indigenous voices were not included in the national narrative about Canada's history. Because of this division, as Mackey (2012: 321) has pointed out, Indigenous peoples were positioned as a commodity of national cultural property - in service to the settler nation:

The Grand Hall is designed to be one of the first spaces a visitor enters and is organized hierarchically - designed to draw people and control movements in specific ways. A breathtaking space of huge proportions, filled with totem poles and artefacts of Canada's West Coast peoples, it curves around the central courtyard of the museum and looks out across the river to Canada's Parliament Buildings. The director of the museum argues that the Grand Hall is made central to the design of the museum so that it will 'emphasize the contributions of Native peoples to the heritage of the nation and the world'... The process of transforming Aboriginal culture into 'heritage' enables the culture of the colonized to be put into the service of building national and international identity.

Such a positioning of Indigenous peoples as 'heritage', Mackey argues, impacts on how students and visitors learn to perceive the Indigenous past. First, Indigenous peoples are idealized as an element of nature itself - they are the 'raw material for the civilizing work of settlement' and the subject of progress, as ordinary Canadians are positioned as the 'agents who transform raw nature into developed civilization' (ibid.: 320). Second, as cultural property of the nation, Indigenous peoples are positioned as the ancestors of a settler nation that has reaped their inheritance - 'not the survivors of conquest and colonization' (ibid.: 321). Third, Indigenous peoples are presented as caught in the past - preserved in time, as relics from a long-forgotten way of doing things. In the words of Mackey (ibid.: 322), they become 'frozen in the glorious past of tepees and headdresses'. From a pedagogical point of view, such positioning can be terribly misleading, since, as Mackey (ibid.) points out:

Most Native people in Canada do not live in tepees. As citizens of the twenty-first century with a long history of colonization, many live in poverty in small, unromantic homes on reserves, in apartments and houses in urban centers, or on the streets.

Perhaps more importantly, it also undermines the position of Indigenous peoples with regard to Treaty Rights and land claims in Canada.

While the Canadian Museum of Civilization has since undergone a name change, becoming the Canadian Museum of History (marking a shift in emphasis towards Canadian history), the dynamics of the Grand Hall remain unchanged. What has changed, 
however, is the positioning of Indigenous peoples in the history of ordinary Canadians in the Canadian History Hall. By weaving Indigenous history into the national narrative of Canada, Indigenous peoples are no longer presented as relics from the past, but rather as survivors and activists in the struggle against settler colonialism.

\section{7 - Stories of Canada: The new Canadian History Hall}

The Canadian History Hall (Canadian Museum of History, n.d.(b)) reopened on 1 July 2017 as a signature exhibition celebrating Canada's sesquicentennial of Confederation (see Figure 4). This completely new exhibition space occupies the same square footage as the previous exhibition, and presents a concise overview of Canadian history, stretching from time immemorial to the present. The intent of this new national narrative is to present multiple stories and multiple experiences within one central storyline, about a Canada that has evolved into a world-leading nation. This is achieved by adopting a 'warts and all' approach to exploring the lives of 'those who helped shape the country we know today ... [and as a way of inspiring] visitors to see themselves as tomorrow's history-makers' (Amyot et al., 2017: 20). This is achieved through a combination of didactic and experiential learning environments, the design of which was driven by six guiding principles:

(1) national narrative - stories that have shaped the country

(2) legacy - for the present and future

(3) authenticity - with 'no re-enactments or generic composites'

(4) human experience of real people - identified by name

(5) multiple perspectives - with particular attention to gender, class, ethnicity and regional distinctions

(6) participation through visitor engagement (ibid.: 22).

What is perhaps most distinctive about the current version of Canada's History Hall is that it includes Indigenous history throughout the entire storyline. In this national vision, Canada begins with a creation story from time immemorial, and the common narrative thread for interpreting Canada's past is a reoccurring pattern of adaptation, disruption and accommodation. The 'big idea' is that Canada is a nation born out of dichotomies of conflict, struggle and loss -along with success, accomplishment and hope.

The exhibition space is divided into three gallery sections, each containing 18 different stories. The first gallery commences with 'Early Canada' (including an Anishinabe creation story) and covers a period up to the British Conquest of New France in 1763. The second gallery commences with 'Colonial Canada' during the time period of British North America, and covers a period up to expansion into the west and the women's suffrage movement of 1916. The third gallery explores an independent 'Modern Canada' initiated by Canada's role in the First World War, and addresses such dichotomies in modernism as internment camps, poverty, gender discrimination, racial discrimination, anti-Semitism, Residential Schools for Indigenous children, Quebec's struggle for independence, language rights and LGBT (lesbian, gay, bisexual and transexual) rights. Moving through these themes of conflict, struggle and loss, the new Canadian History Hall concludes with multiple messages of success, accomplishment and hope. These messages include such themes as Indigenous rights, welcoming refugees, international peacekeeping, and international leadership in innovation and technology. The History Hall then ends with a patriotic celebration of Canada as a world leader in peace, democracy and human rights. 


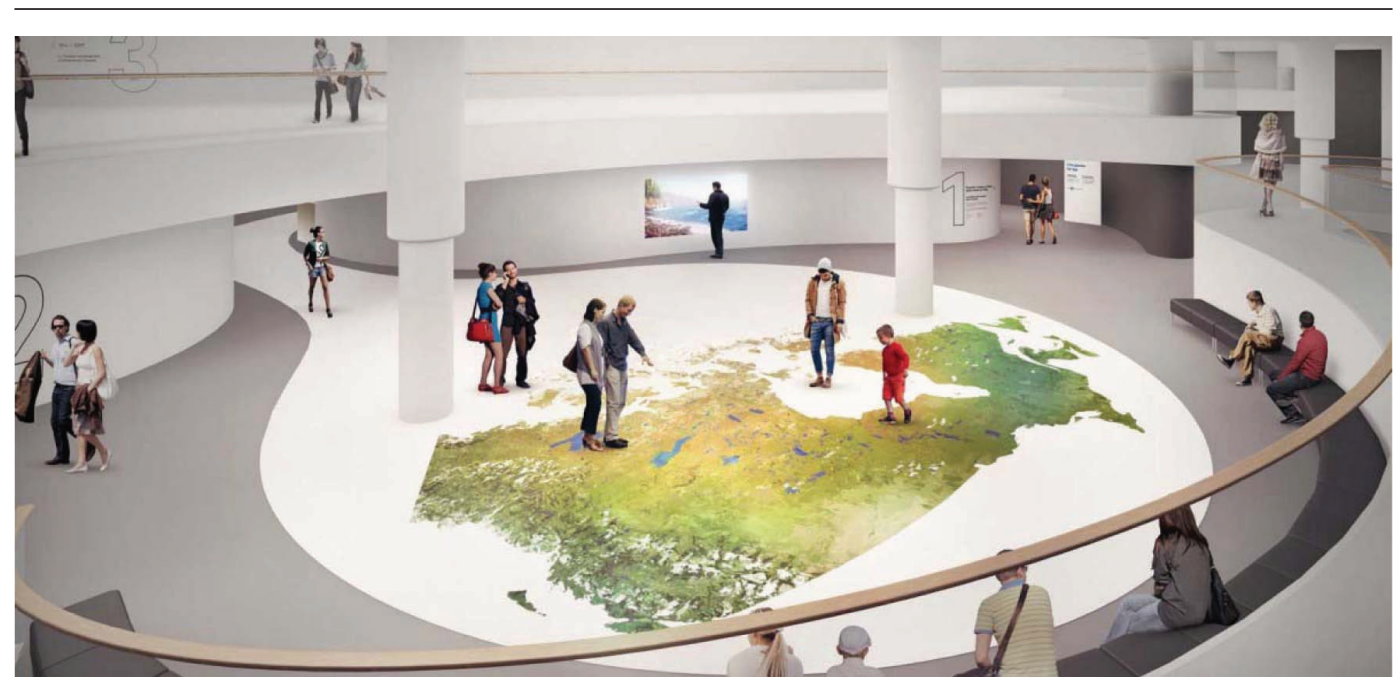

Credit: Canadian Museum of History

Figure 4: The new Canadian History Hall, presenting a concise overview of Canadian history, stretching from time immemorial to the present

What is perhaps most important about the overall storyline for this version is that Indigenous peoples are no longer presented as relics from the past, but rather as survivors and activists in a struggle against settler colonialism. This is achieved by weaving Indigenous history into the national narrative of all three galleries in the hall. In addition, there is a section within the third gallery devoted specifically to First Peoples and Aboriginal rights. Entering this space, visitors are first confronted with the words of Duncan Campbell Scott, who was the Deputy Superintendent of Indian Affairs in 1920: 'Our object is to continue until there is not a single Indian in Canada that has not been absorbed into the body politic.' What follows are didactic panels, highlighted by Indigenous voices from the past, relating to 'Cultural Oppression', 'Colonialism in the North', 'Indian Residential Schools', 'Speaking Out', 'Rediscovered Voices', 'Leadership and Self-determination', 'Cultural Affirmation', 'The Importance of Women' and 'Land and Aboriginal Rights'. This section ends with an affirmation of youth, featuring an optimistic final statement that 'Indigenous peoples are gradually regaining control of their cultural identity, their governments, and their territories. Challenges abound, but there is hope and untold possibility' (Amyot et al., 2017: 199). This is the narrative that students encounter when they visit the new Canadian History Hall in 2018.

\section{Truth and reconciliation}

In examining various manifestations of national narratives that have constituted Canada's History Hall (Canadian Museum of History, n.d.(b)), it becomes apparent how the storyline has evolved out of a colonial past. What is most significant about this evolution, however, is how Indigenous history has only recently been fully integrated into the museum's national narrative about Canada. This has come about mainly in response to nationwide hearings and the subsequent findings of Canada's Truth and Reconciliation Commission (TRC). As is noted in the TRC's final report, the Canadian Museum of History has acknowledged the previous absence of Indigenous voices in the museum's national narrative. Appearing before the House of Commons Standing Committee on Canadian Heritage in 2013 (at a time when the new History Hall was 
under development), museum President and Chief Executive Officer, Mark O'Neill, publicly recognized these inadequacies:

Canadians made it very clear to us during the public engagement process that the voices and the experiences of First Peoples must have a place in any narrative of Canadian history ... Canadians want us to be comprehensive, frank, and fair in our presentation of their history. They want us to examine both the good and the bad from our past. We were urged to foster a sense of national pride without ignoring our failings, mistakes and controversies. (Truth and Reconciliation Commission, 2015a: 135)

The museum's resulting research strategy, which is intended to guide the institution until 2023, includes a key research theme that focuses on Indigenous (Aboriginal) history as part of a broader national narrative:

Respectful exploration of the interwoven, often difficult histories of Aboriginal and non-Aboriginal Peoples, is a responsible, timely contribution to contemporary Canada, and to global understanding of Aboriginal Peoples ... there are four principal objectives in exploring and sharing Aboriginal narratives ... 1) Represent Aboriginal histories and cultures within broader Canadian narratives ... 2) Explore inter-cultural engagement and its continuing impacts ... 3) Broaden understanding of Aboriginal history before European contact ... [and] 4) Deepen efforts to support First Peoples' stewardship. (ibid.)

A commitment to these strategic goals is apparent in the current storyline for Canada's History Hall. In turn, the Truth and Reconciliation Commission has issued a total of 94 calls to action, one of which includes 'building student capacity for intercultural understanding, empathy, and mutual respect' (Truth and Reconciliation Commission, 2015b: 7).

\section{Significance to history education}

As findings from the national survey Canadians and their Pasts (Conrad et al., 2013) indicate, museums have an important role to play in history education. Findings indicate that the largest proportion of Canadians (more than 60 per cent) find museums to be very trustworthy; this level of trust is substantially higher than for history books, history teachers or the internet (50 per cent). Canadians' reasoning is based upon 'confidence in the expertise of professional historians who curate museum exhibits' (ibid.: 18). Many also state that 'exposure to museums at an early age' has had 'an important impact on their continued involvement' (ibid.). By comparison, my own research has revealed that middle-school students (Grade 7) place an even higher level of trust in museums (Wallace-Casey, 2015). Students' reasoning is based upon a belief that museums present 'real things' or 'artefacts,' and safeguard 'knowledge' or 'proof'. These findings point to the pedagogical significance of museums as dynamic places for learning about the past.

Operating somewhat in parallel to the Canadians and their Pasts initiative, social studies curricula across Canada have undergone substantial revisions. As a result, historical thinking (a history domain-based approach to history education) has become firmly embedded within the curricula of most provinces and territories, including Ontario, British Columbia, Manitoba, New Brunswick, Newfoundland and Labrador, Northwest Territories, Nova Scotia, and Nunavut (Seixas and Colyer, 2014). 
Such pedagogical developments are immensely relevant to museum education, since dramatic changes in how students are expected to learn about the past require that history museums re-evaluate how they design and deliver student programmes. Coupled with these new developments are various academic debates regarding public pedagogy, difficult knowledge and nationalism (Epstein and Peck, 2018; Gosselin and Livingstone, 2016; Kosasa, 2011; Lehrer et al., 2011; Mackey, 1999, 2012; MacMillan, 2009; Morgan, 2016; Neatby and Hodgins, 2012; Stanley, 2006; Trofanenko and Segall, 2014; see also Ahonen, 2001; Berger et al., 2008; Carretero et al., 2017, 2012; Carretero, 2011; Chapman and Wilschut, 2015; Fromm et al., 2014; Levy, 2017; Wertsch, 2017).

In an internationally connected, ever-evolving global landscape, the keepers (and preservers) of Canada's tangible past are called to adjust accordingly (Anderson, 2017; Gosselin and Livingstone, 2016; Lévesque, 2017; Simon, 2011a; see also Adair et al., 2011; Barton, 2006; Barton and McCully, 2005; Golding, 2014; Gosselin, 2011; Grinell, 2014; Harris and Reynolds, 2014; Kelly and Gordon, 2002; Kidd et al., 2014; Kosasa, 2011; Létourneau, 2014; Lévesque, 2006; Marcus et al., 2012, 2017; Marcus and Levine, 2011; Nakou, 2006; Nordgren, 2016; Sandwell, 2012; Silverman, 2010; Simon, 2011b; Trofanenko, 2014; van Boxtel, 2010; van Boxtel et al., 2011). This also requires that researchers develop a better understanding of the national narratives that students construct from the cognitive process of historical thinking in museum spaces such as the current Canadian History Hall. How can students be enabled through historical thinking to deconstruct the narratives they encounter in history museums? What are the narratives that students construct in the process?

\section{Conclusion}

As is evident from examining the narrative templates presented in this paper, Canada's History Hall (Canadian Museum of History, n.d.(b)) provides a reflection upon Canadian society spanning over fifty years. Commencing with Darwinian values, the national narrative has shifted away from a colonial perspective on the past, to more fully integrate Indigenous voices in the narrative mix. This has come about in response to public demands for Truth and Reconciliation in public education forums. Over this period, the Canadian Museum of History has reinvented Canadian identity, moving from political union, to 'a few acres of snow'; and from a place for 'new beginnings', to a world leader in peace, democracy and human rights. This transition marks a trajectory away from colonial sovereignty, where Indigenous voices were blatantly absent, towards a fuller integration of these voices into the national narrative. In so doing, Indigenous peoples have been repositioned within the museum as active agents in Canada's history. More empirical research is required, however, regarding student-visitor historical thinking in Canadian history museums, and whether the narratives that students construct from this process actually addresses the TRC calls to action.

\section{Acknowledgements}

This research is funded by the Social Sciences and Humanities Research Council (SSHRC) of Canada.

\section{Notes on the contributor}

Cynthia Wallace-Casey is a Social Sciences and Humanities Research Council (SSHRC) of Canada postdoctoral research fellow at the University of Ottowa and a member of the 
Making History Education Research Unit. Her doctoral research, from the University of New Brunswick, is in history education. Her postdoctoral research investigates national narratives, difficult histories and historical thinking in museums; she is also exploring the narratives that seventh-grade students take away from museum experiences.

\section{References}

Adair, B., Filene, B. and Koloski, L. (eds) (2011) Letting Go? Sharing historical authority in a usergenerated world. Philadelphia: Pew Center for Arts and Heritage.

Ahonen, S. (2001) 'Politics of identity through history curriculum: Narratives of the past for social exclusion - or inclusion?'. Journal of Curriculum Studies, 33 (2), 179-94.

Amyot, C., Leblanc, L. and Morrison, D. (eds) (2017) Stories of Canada: The Canadian History Hall. Gatineau, QC: Canadian Museum of History.

Anderson, S. (2017) 'The stories nations tell: Sites of pedagogy, historical consciousness, and national narratives'. Canadian Journal of Education, 40 (1), 1-38.

Barton, K.C. (2006) 'History, humanistic education, and participatory democracy'. In Sandwell, R.W. (ed.) To the Past: History education, public memory, and citizenship in Canada. Toronto: University of Toronto Press, 50-69.

Barton, K.C. and McCully, A.W. (2005) 'History, identity, and the school curriculum in Northern Ireland: An empirical study of secondary students' ideas and perspectives'. Journal of Curriculum Studies, 37 (1), 85-116.

Berger, S., Eriksonas, L. and Mycock, A. (eds) (2008) Narrating the Nation: Representations in history, media and the arts. New York: Berghahn Books.

Canadian Museum of History (n.d.(a)) 'Canada Hall'. Online. www.historymuseum.ca/cmc/ exhibitions/hist/canp1/canp1eng.shtml\#menu (accessed 30 October 2017).

Canadian Museum of History (n.d.(b)) 'Canadian History Hall'. Online. www.historymuseum.ca/blog/ category/canadian-history-hall/ (accessed 10 July 2018).

Carretero, M. (2011) Constructing Patriotism: Teaching history and memories in global worlds. Charlotte, NC: Information Age Publishing.

Carretero, M., Asensio, M. and Rodríguez-Moneo, M. (eds) (2012) History Education and the Construction of National Identities. Charlotte, NC: Information Age Publishing.

Carretero, M., Berger, S. and Grever, M. (eds) (2017) Palgrave Handbook of Research in Historical Culture and Education. London: Palgrave Macmillan.

Champoux-Ares, L. (1986) History Hall exhibit communications plan: Audiences and exhibit objectives. Unpublished manuscript. National Museum of History Archives, H-260, f.6.

Chapman, A. and Wilschut, A. (eds) (2015) Joined-Up History: New directions in history education research. Charlotte, NC: Information Age Publishing.

Conrad, M., Ercikan, K., Friesen, G., Létourneau, J., Muise, D., Northrup, D. and Seixas, P. (2013) Canadians and Their Pasts: The pasts collective. Toronto: University of Toronto Press.

Epstein, T. and Peck, C.L. (eds) (2018) Teaching and Learning Difficult Histories in International Contexts: A critical sociocultural approach. London: Routledge.

Friesen, J. (1978) 'National Museum of Man, "A few acres of snow/Quelques arpents de neige"'. Material History Bulletin, 5, 55-65. Online. https://journals.lib.unb.ca/index.php/MCR/article/ view/16978/18253 (accessed 30 October 2017).

Fromm, A.B., Golding, V. and Rekdal, P.B. (eds) (2014) Museums and Truth. Newcastle upon Tyne: Cambridge Scholars Publishing.

Gallacher, D. (2009) The Canada Hall: A museum approach to epic history. Unpublished manuscript. National Museum of History, 2009-H0011/H-547,F4.

Golding, V. (2014) 'Museums and truths: The elephant in the room'. In Fromm, A.B., Golding, V. and Rekdal, P.B. (eds) Museums and Truth. Newcastle upon Tyne: Cambridge Scholars Publishing, 3-20.

Gosselin, V. (2011) 'Historical thinking in the museum: Open to interpretation'. In Clark, P. (ed.) New Possibilities for the Past: Shaping history education in Canada. Vancouver: University of British Columbia Press, 245-63.

Gosselin, V. and Livingstone, P. (eds) (2016) Museums and the Past: Constructing historical consciousness. Vancouver: University of British Columbia Press.

Grinell, K. (2014) 'Challenging normality: Museums in/as public space'. In Fromm, A.B., Golding, V. and Rekdal, P.B. (eds) Museums and Truth. Newcastle upon Tyne: Cambridge Scholars Publishing, 169-88. 
Haque, E. (2012) Multiculturalism within a Bilingual Framework: Language, race, and belonging in Canada. Toronto: University of Toronto Press.

Harris, R. and Reynolds, R. (2014) 'The history curriculum and its personal connection to students from minority ethnic backgrounds'. Journal of Curriculum Studies, 46 (4), 464-86.

Hayday, M. (2017) 'Sir Hector-Louis Langevin, "architect" of residential schools?'. Active History, 23 June. Online. http://activehistory.ca/2017/06/langevin/ (accessed 30 October 2017).

Kelly, L. and Gordon, P. (2002) 'Developing a community of practice: Museums and reconciliation in Australia'. In Sandell, R. (ed.) Museums, Society, Inequality. London: Routledge, 153-74.

Kidd, J., Cairns, S., Drago, A., Ryall, A. and Stearn, M. (eds) (2014) Challenging History in the Museum: International perspectives. Farnham: Ashgate.

Kosasa, K.K. (2011) 'Searching for the "C" word: Museums, art galleries, and settler colonialism in Hawai'i'. In Bateman, F. and Pilkington, L. (eds) Studies in Settler Colonialism: Politics, identity and culture. Basingstoke: Palgrave Macmillan, 153-68.

Lehrer, E., Milton, C.E. and Patterson, M.E. (eds) (2011) Curating Difficult Knowledge: Violent pasts in public places. Basingstoke: Palgrave Macmillan.

Létourneau, J. (2014) Je me souviens? Le passé du Québec dans la conscience de sa jeunesse. Montreal: Fides.

Lévesque, S. (2006) 'Integrating museum education and school history: Illustrations from the RCR Museum and London Museum of Archaeology'. International Journal of Historical Learning, Teaching and Research, 6, 40-7.

Lévesque, S. (2017) 'History as a "GPS": On the uses of historical narrative for French Canadian students' life orientation and identity'. London Review of Education, 15 (2), $227-42$.

Levy, S.A. (2017) 'How students navigate the construction of heritage narratives'. Theory and Research in Social Education, 45 (2), 157-88.

MacDonald, G.F. and Alsford, S. (1989) A Museum for the Global Village: The Canadian Museum of Civilization. Gatineau, QC: Canadian Museum of Civilization.

Mackey, E. (1999) The House of Difference: Cultural politics and national identity in Canada. London: Routledge.

Mackey, E. (2012) 'Tricky myths: Settler pasts and landscapes of innocence'. In Neatby, N. and Hodgins, P. (eds) Settling and Unsettling Memories: Essays in Canadian public history. Toronto: University of Toronto Press, 310-39.

MacMillan, M. (2009) Dangerous Games: The uses and abuses of history. New York: Modern Library.

Marcus, A.S. and Levine, T.H. (2011) 'Knight at the museum: Learning history with museums'. Social Studies, 102 (3), 104-9.

Marcus, A.S., Levine, T.H. and Grenier, R.S. (2012) 'How secondary history teachers use and think about museums: Current practices and untapped promise for promoting historical understanding'. Theory and Research in Social Education, 40 (1), 66-97.

Marcus, A.S., Stoddard, J.D. and Woodward, W.W. (2017) Teaching History with Museums: Strategies for K-12 social studies. 2nd ed. New York: Routledge.

Morgan, C. (2016) Commemorating Canada: History, heritage, and memory, 1850s-1990s. Toronto: University of Toronto Press.

Nakou, I. (2006) 'Museums and history education in our contemporary context'. International Journal of Historical Learning, Teaching and Research, 6, 83-92.

National Museum of Man (1977) Backgrounder: 'A few acres of snow'. Unpublished manuscript. National Museum of History Archives, 436, f.11.

Neatby, N. and Hodgins, P. (eds) (2012) Settling and Unsettling Memories: Essays in Canadian public history. Toronto: University of Toronto Press.

Nordgren, K. (2016) 'How to do things with history: Use of history as a link between historical consciousness and historical culture'. Theory and Research in Social Education, 44 (4), 479-504.

Rider, P.E. (1994) 'Presenting the public's history to the public: The case of the Canadian Museum of Civilization'. In Rider, P.E. (ed.) Studies in History and Museums. Gatineau, QC: Canadian Museum of Civilization, 77-101.

Ruddel, D.T. (1983) Canadians and Their Environment. Ottawa: National Museum of Man.

Sandwell, R. (2012) "'We were allowed to disagree, because we couldn't agree on anything": Seventeen voices in Canadian debates over history education'. In Taylor, T. and Guyver, R. (eds) History Wars and the Classroom: Global perspectives. Charlotte, NC: Information Age Publishing, 51-76.

Secretary of State (1964) Report of the Secretary of State of Canada for the Year Ended March 31, 1964. Ottawa: Queen's Printer. 
Secretary of State (1965) Report of the Secretary of State of Canada for the Year Ended March 31, 1965. Ottawa: Queen's Printer.

Secretary of State (1968) Report of the Department of the Secretary of State of Canada for the Year Ending March 31, 1968. Ottawa: Queen's Printer.

Seixas, P. and Colyer, J. (2014) From the Curriculum to the Classroom: More teachers, more students, more thinking. Vancouver: University of British Columbia. Online. http://historicalthinking.ca/sites/default/files/files/docs/HTP2014_EN.pdf (accessed 12 July 2018).

Silverman, L.H. (2010) The Social Work of Museums. London: Routledge.

Simon, N. (2011a) 'Participatory design and the future of museums'. In Adair, B., Filene, B. and Koloski, L. (eds) Letting Go? Sharing historical authority in a user-generated world. Philadelphia: Pew Center for Arts and Heritage, 18-33.

Simon, R.I. (2011b) 'Afterword: The turn to pedagogy: A needed conversation on the practice of curating difficult knowledge'. In Lehrer, E., Milton, C.E. and Patterson, M.E. (eds) Curating Difficult Knowledge: Violent pasts in public places. Basingstoke: Palgrave Macmillan, 193-209.

Stanley, T.J. (2006) 'Whose public? Whose memory? Racisms, grand narratives and Canadian history'. In Sandwell, R.W. (ed.) To the Past: History education, public memory, and citizenship in Canada. Toronto: University of Toronto Press, 32-49.

Thorpe, F.J. (1978) 'The Canadian history hall: Concepts and consideration'. Material History Bulletin, 5, 66-8. Online. https://journals.lib.unb.ca/index.php/MCR/article/view/16978/18253 (accessed 10 January 2018).

Thorpe, F. (c.1980) 'From Logan's rocks to a "few acres of snow": The National Museum of Man's history exhibition in historical perspective'. Unpublished manuscript, Canadian Museum of History, 2001-I0036_2003-I0013/I-9b,f2.

Trofanenko, B. (2014) 'On the museum as a practised place: Or, reconsidering museums and history education'. In Sandwell, R. and von Heyking, A. (eds) Becoming a History Teacher: Sustaining practices in historical thinking and knowing. Toronto: University of Toronto Press, 269-82.

Trofanenko, B. and Segall, A. (eds) (2014) Beyond Pedagogy: Reconsidering the public purpose of museums. Rotterdam: Sense Publishers.

Truth and Reconciliation Commission of Canada (2015a) Canada's Residential Schools: Reconciliation: The final report of the Truth and Reconciliation Commission of Canada (Vol. 6). Montreal: McGill-Queen's University Press.

Truth and Reconciliation Commission of Canada (2015b) Truth and Reconciliation Commission of Canada: Calls to action. Winnipeg: Truth and Reconciliation Commission of Canada. Online. www.trc.ca/websites/trcinstitution/File/2015/Findings/Calls_to_Action_English2.pdf (accessed 30 October 2017).

van Boxtel, C. (2010) 'Something to talk about? The potential of a dynamic approach of heritage in heritage education'. EuroClio Bulletin, 30, 53-63.

van Boxtel C., Klein S. and Snoep E. (eds) (2011) Heritage Education: Challenges in dealing with the past. Amsterdam: Erfgoed Nederland.

Vodden, C. and Dyck, I. (2006) A World Inside: A 150-year history of the Canadian Museum of Civilization. Gatineau, QC: Canadian Museum of Civilization.

Voltaire (1759) Candide. Blackmask Online. Online. www.ebooksgratuits.com/blackmask/voltaire_ candide.pdf (accessed 10 January 2018).

Wallace-Casey, C.D. (2015) 'Deepening Historical Consciousness through Museum Fieldwork: Implications for community-based history education'. Unpublished PhD thesis, University of New Brunswick.

Wertsch, J.V. (2017) 'Foreword to the special feature "Negotiating the nation: Young people, national narratives and history education", edited by Jocelyn Létourneau and Arthur Chapman'. London Review of Education, 15 (2), 152-3. 